\title{
Incorporating Sustainability into the Academic Institution
}

\author{
Charlotte Sinden, Cardiff University
}

\section{Abstract}

This research examines environmental sustainability in the UK university context. Universities are prioritising sustainability commitments with many declaring a climate emergency, as well as recognising the importance of educating students about climate change. Using a case-study approach in which semi-structured interviews were coupled with secondary data analysis, this research highlights that universities are pivotal for greater environmental sustainability. The results reiterate the urgent need to significantly improve environmental performance and educate people in the field of sustainability, while also presenting the challenges and realities faced in doing so. It is recommended that in order to achieve optimal sustainability solutions, a cohesive approach is required to embed a common sustainability narrative for all.

Keywords: Responding to the climate emergency, climate change, environmental sustainability in higher-education institutions, incorporating sustainability into strategies

\section{Introduction}

Since emerging as a concept in the 1980s, sustainable development has become a central concept for our age (Sachs, 2015b). Often termed the 'Anthropocene', scientists believe we have now entered a new historical epoch in which humans themselves are the dominant force for planetary change (Crutzen, 2006). Sustainable development is both a way of understanding the world and a method for solving global problems (Sachs, 2015b). This research is timely given stark claims from the Intergovernmental Panel on Climate Change (IPCC) report (2018) that warned that allowing temperatures to rise more than $1.5^{\circ} \mathrm{C}$ will have catastrophic, and potentially irreversible, effects on the planet. The IPCC is a global body assessing the science relating to climate change and has not typically published such urgent warnings, thus indicating the severity of the situation. Based on this backdrop of mounting climate uncertainty, this research 
Reinvention: an International Journal of Undergraduate Research 14:1 (2021) assesses how environmental sustainability is incorporated in the higher-education context focusing on Cardiff University as a case study.

Many universities have prioritised sustainability in response to international conventions, such as the UN Sustainable Development Goals (SDGs) and the Paris Agreement (2015) (Soini et al., 2018). The SDGs consist of 17 goals and 169 targets addressing all aspects of sustainability, becoming a global initiative to end poverty, protect the planet and to ensure peace and prosperity for all. Yet critical observers believe the SDGs adopt a neoliberal, anthropocentric vision whereby the environment is often assigned secondary value after economic and social concerns (Kopnina, 2016). O’Neill et al., (2018) believe a more hopeful scenario would see the SDGs shift the agenda away from economic growth towards a new model where the goal is sustainable and equitable human wellbeing. Regardless of this, following government agendas to make the SDGs successful, Sachs (2015a) argues that universities globally should play a bold role in their implementation. Applying the SDGs at the national scale, the Welsh government has a clear legislative pathway for the SDGs and specifically for environmental sustainable development (see Figure 1).

A screenshot of a cell phone

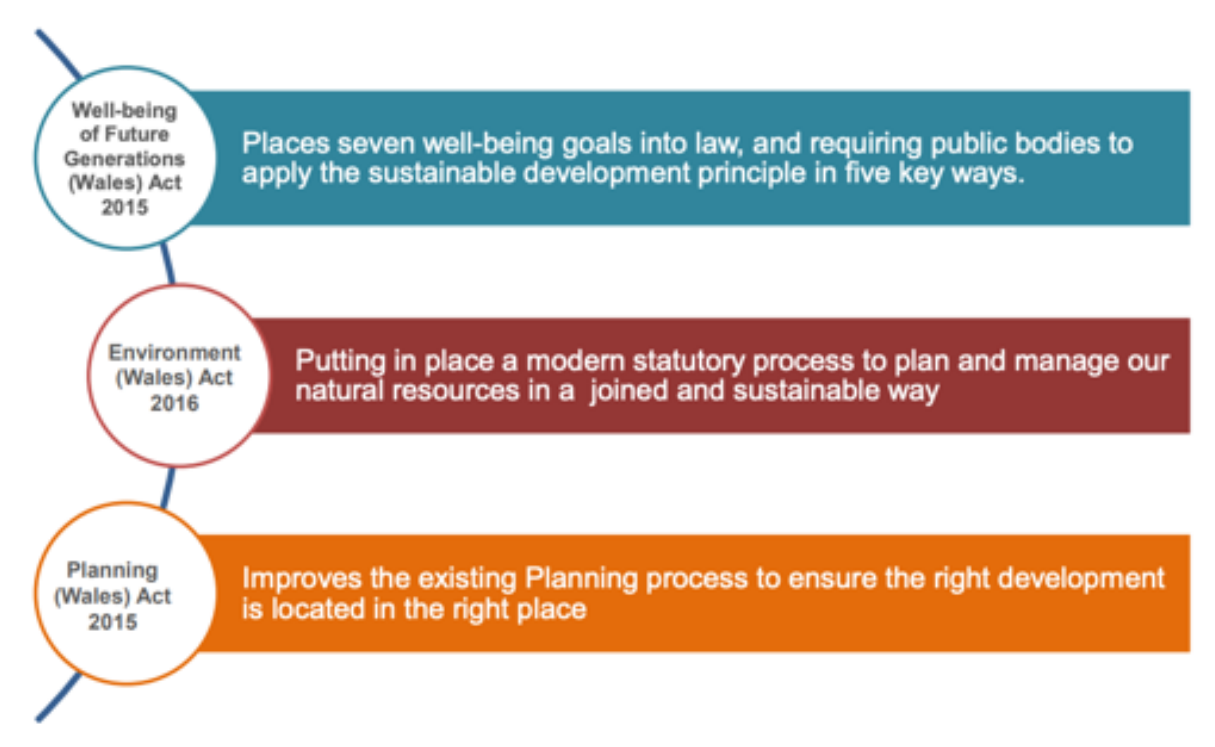

Figure 1: Legislation for sustainable development to secure the long-term wellbeing of Wales (Welsh Assembly Government, 2016)

This research seeks to explore how Cardiff University engages with environmental sustainability, guided by the following research questions:

- How is sustainability researched and taught across the university? 
- How is the university incorporating sustainability into its practical operations?

This research builds on existing academic literature regarding sustainability in the higher-education context, taking a social constructivist approach to explore new meanings and perspectives on the continuously evolving sustainability debate. As a research-intensive institution, Cardiff University has a clear vision to improve its environmental performance.

\section{Literature review}

Introducing sustainable development

Sustainable development remains a largely ambiguous concept (Pesqueux, 2009), yet acts as a driving force dominating global political discussion in the twenty-first century. The broad notion of sustainable development first emerged in the 1970s with the realisation that the economic boom of the 1950s and 1960s was having a destructive effect on the environment (Pesqueux, 2009: 231). Sustainable development is problematic to define, adopting different meanings in varying contexts (Pierantoni, 2004; Sikdar, 2012). The Brundtland Report (UNWCED, 1987) famously defined sustainable development as 'development which meets the needs of the present, without compromising the ability of future generations to meet their own needs' (UNWCED, 1987: 43). Conca et al., (2001) criticise the Brundtland definition, asserting that what may constitute the 'needs of current and future populations' remain subjective and open to change. Over time, sustainability has evolved practically as well as philosophically - focusing less on intergenerational needs and more on the holistic approach linking economic development, social inclusion and environmental sustainability (Sachs, 2015b). However, economic development remains dominant in many definitions. Given the multifarious nature of sustainable development, this research focuses specifically on environmental sustainability.

\section{Environmental sustainable development}

Until the 1980s, it was commonly argued that economic and environmental aims were intrinsically opposed, with human development prioritised over the natural environment (Castree et al., 2013). However, in the 1990s, the theory of ecological modernisation emerged as a new paradigm representing the possibility for economic growth that was, in theory, environmentally benign (Young, 2015). This sparked extensive debate regarding whether greening contemporary capitalism offers optimal 
Reinvention: an International Journal of Undergraduate Research 14:1 (2021) sustainability solutions or delays radical environmental reform (Mol and Spaargaren, 2000). Nevertheless, emissions have continued to rise, and Gills and Morgan (2020: 886) state that 'on a global basis, July 2019 was the hottest month ever recorded. NASA data on global warming indicates that 17 of the 18 hottest years ever recorded in the past 136 years were during 2001-2018'. Thus, many recognise the current state of the global natural environment as the most urgent and significant challenge in recent history (Ralph and Stubbs, 2013; McCullough et al., 2016), suggesting the necessity of critical action.

Within this debate, there has been a transition from 'government' to 'governance', attempting to 'include wider parts of society through multi-level government involvement' (Berger, 2010: 231). Governance expresses that the state increasingly depends on other organisations to secure its intentions, deliver its policies and tackle the changing nature of complex environmental problems faced in the twenty-first century (Bevir, 2008). Huxley et al., (2019) argue that governments can affect only a small percentage of emissions directly and must work in partnership to lower emissions. Essentially, environmental sustainability requires strong, sustained and interdisciplinary commitments to induce effective transformative change across environmental arenas (Sterling, 2013; Chowdhury et al., 2019).

\section{Environmental sustainability in policy frameworks}

Governments and other actors have introduced policies to tackle environmental issues at a range of geographical scales. Policies such as the UN SDGs (2015) give direction, while the Paris Agreement encourages countries to demonstrate their Intended Nationally Determined Contributions for tackling climate change. Following the Earth Summit (1992) - a global conference held to reconcile worldwide economic development while limiting environmental degradation - recognition emerged that all levels of governance must be involved to achieve the proposed global plan for sustainable development (Evans and Theobald, 2003). These global-scale policies and Accords manifest in different ways at multiple scales: in Wales, the Wellbeing of Future Generations Act (2015) sets out how the SDGs should be implemented, making sustainability a national priority (Welsh Assembly Government, 2019).

Similarly, higher-education institutions have responded to calls for climate action by signing numerous declarations. The role of higher education in sustainability was first recognised at the first UN conference on the Human Environment, the Stockholm Conference (1972), which formally documented the role of higher education in 
Reinvention: an International Journal of Undergraduate Research 14:1 (2021)

fostering environmental protection (Lozano et al., 2011). This catalysed a series of subsequent declarations, such as the Talloires Declaration (1990): 10-point action plan addressing problems of environmental decline and the importance of embedding a sustainability narrative across higher-education institutions (ULSF, 1990). These declarations, although implementing sustainability programmes differently, lay the foundations for effective tailored sustainability policies within universities (Clarke and Kouri, 2009). The next section explores how universities translate environmental sustainability policies into practical operations and education.

\section{Environmental sustainable development in higher education}

An ecologically sound society requires strong support from universities (Wang et al., 2013) as they can influence future generations (Piza et al., 2018). Higher-education institutions appear to have a double role through research and teaching - creating knowledge for global benefits and integrating this in education, thus preparing students for their future societal roles (Stough et al., 2016). Universities' transition to sustainability involves all areas of activity, meaning the process is long and often characterised by resistance - such as financial constraints and lack of enforcement (Hoover and Harder, 2015). Universities are beginning to re-orient their education, research and operations towards sustainability (Wals, 2014), but, despite progress, sustainability is yet to fully permeate all aspects of university practice and teaching.

Many efforts have been made to lessen environmental impacts while promoting sustainability at higher-education institutions, albeit often from an ecological modernisation approach. The greening of universities involves the process of reducing environmental impacts from campus activities, alongside raising awareness of how to act more sustainably (Creighton, 1999). Some universities have adopted a 'living lab' approach, addressing real-life sustainability problems through collaborative experiments that integrate users and various stakeholders as co-producers of knowledge (Evans et al., 2015). As such, universities can teach and demonstrate how environmental protection play out on a day-to-day basis while highlighting future possible, more sustainable, worlds (Dahle, 2001). Universities have potential to represent a 'green model' by gathering and sharing innovative ideas of how to tackle environmental issues (Dahle, 2001: 154), acting as 'small cities' that can have substantial impact - and large influence - on their surroundings (Ragazzi and Ghidini, 2007: 112). Yet Sterling (2013) warns that where sustainability is acknowledged, it 

interdisciplinary transformation.

Thus, it is also important to explore environmental and climate literacy. During recent decades, education has emerged as critical in transforming societies towards a sustainable trajectory, as curricula incorporate sustainability (Ramos et al., 2015). Ralph and Stubbs (2013: 73) demarcate a 'third wave of sustainability' in higher education: a movement focusing more on education than the greening of physical campus infrastructure. Curriculum change is driven by moral obligations to act on environmental issues but proves to be a complex task requiring a transformative shift in the topics that are researched and taught (Ralph and Stubbs, 2013). Lozano et al., (2011: 12) identify what they see as the main reasons for universities lacking engagement in sustainable education: over-crowded curricula, little (perceived)

relevance to the course, academic credibility and path dependency. Compartmentalisation of university disciplines also often makes it difficult to share knowledge and expertise across subject boundaries, resulting in constrained sustainability efforts (Adomßent et al., 2019), despite scholars believing sustainability should be treated as an interdisciplinary concept (Moore, 2005). Further, Kopnina (2012) notes that education for sustainable development should not be confused with environmental education, as the former is deeply contested: building upon neoliberal paradigms that position environmental protection as an afterthought, in contrast to placing the environment to the fore.

Sustainable development is complex by nature, hard to define or measure, and yet imperative for education and research given existential threats such as climate change (Hamilton, 2016). This literature review suggests that, despite the interest of highereducation institutions in tackling environmental sustainability, the extent to which they incorporate sustainability varies. Highlighted by the 'Wellbeing of Future Generations Act' (2015), Wales has a clear vision for sustainability. This research, then, examines how Cardiff University is tackling the abstruse concept of environmental sustainability in a country with a strong policy framework for sustainable development.

\section{Research methods}

This research employed semi-structured interviews, which generated detailed qualitative data to give an authentic insight into people's experiences, thus enabling rich examination of sustainability at Cardiff University (Silverman, 2001; Jamshed, 
Reinvention: an International Journal of Undergraduate Research 14:1 (2021) 2014). Secondary data analysis of Cardiff University's sustainability strategies complemented the primary data, highlighting the importance of adopting a mixedmethod approach. I developed an inductive thematic framework, so constructed themes that emerged from the primary research (Braun and Clarke, 2013). Adopting these methods allowed observation of how sustainability is conceptualised and operationalised across Cardiff University by different actors, enabling a discussion of the wider processes underpinning sustainability, but also with potential to undermine sustainability narratives in the higher-education context.

\section{Semi-structured interviews}

The main method used for this research was semi-structured interviews. I conducted 13 interviews with university staff, including those involved with implementing sustainable practice (estates-based participants) and experts who research and teach sustainability (i.e. professional services and academic faculty). Semi-structured interviews provide a flexible technique for small-scale research because questions can be adapted, allowing for unexpected answers while also clarifying the interviewee's response (Drever, 1995; Elliot et al., 2016). This approach often facilitates a deeper insight into respondents' views (Taylor et al., 2015). I developed two interview schedules to account for this practice and research distinction (see Appendices 1 and 2). Although many responses overlapped each research aim, separate schedules allowed for a deeper analysis depending on whether sustainability in education or sustainability in practical operations was being examined.

Interviewees were selected first through a purposive sampling technique. This involved selecting individuals that are especially knowledgeable about or experienced with environmental sustainability from multiple academic disciplines (Cresswell and Clark, 2011). Internet searches enabled me to identify professionals whose research and teaching specialises in sustainability, and estates-based staff who implement campus sustainability projects. I also used snowball sampling alongside purposive sampling as this provided a wider research cohort (Palinkas et al., 2015). Vogt (1999) describes snowball sampling as one subject recruiting further suitable participants through their acquaintances, allowing the researcher access to participants who would have otherwise been unknown. Arguably, only interviewing sustainability professionals and not those who disregard environmental issues can be seen as a limitation in this study. Nevertheless, conducting semi-structured interviews using 
these sampling techniques allowed a rich examination into sustainable development at Cardiff University, according to those interviewed.

\section{Secondary data analysis}

To complement this primary research, secondary sources such as the Environmental Sustainability Enabling Strategy (ESES) (Cardiff University, 2018) and the Environmental Sustainability Action Plan (ESAP) (Cardiff University, 2018) were analysed to explore strategic priorities and to identify gaps between policies and practice. As Elo and Kyngäs (2008: 114) note, secondary sources offer a 'snapshot' of activities occurring in institutions; thus, this complemented the primary research.

It is important to acknowledge the benefits and limitations of conducting a small-scale study. While focusing on one case study allows for a detailed examination into the topics discussed, the results cannot be generalised for the whole population, as subjective conclusions can be generated (Gerring, 2006). Nevertheless, the data analysis can be indicative of how sustainability is contextualised in the wider highereducation context while showing the complexities of incorporating it across governance structures within specific institutions. Secondary literature was integrated into the analysis to induce a more critical engagement with the interview responses while also limiting bias of focusing on a single case study. This, then, represents a call for action for all universities to embed sustainability across their institutions.

\section{Data analysis}

The analysis presented here adopts a thematic approach, combining key ideas with extant literature to explore environmental sustainability at Cardiff University. First, I explore academic staff perceptions regarding the importance of educating and researching sustainability and how this differs across the institution. Next, I look at how Cardiff University integrates environmental sustainability across their practical operations.

\section{The role of education in achieving sustainability}

Participants were asked about their understandings of sustainability and the significance of the concept to gain insight into the role and importance of incorporating it across the academic institution. All participants highlighted that researching and educating for sustainability is imperative. Participant 3 contends that: 
It is crucial to get students interested in this topic. If you look at the reports from the IPCC, it's clear we need to fundamentally change the way that we live so that sustainability is a central part of what we are doing and what we are thinking about.

For Participant 3, the IPCC is a key actor in guiding change, and, for this international climate change researcher, such change must be fundamental across all dimensions of society, suggesting a break from more incremental approaches typically found in policy (Aldunce et al., 2016). Ensuring that students understand the findings of reports such as the IPCC report (2018) is critical: students need to be made aware of the implications of allowing temperatures to rise more than $1.5^{\circ} \mathrm{C}$ this century. Furthermore, Participant 12 stresses the need for balance discussing the global challenges and the kinds of solutions that might be possible:

Our job as educators is not to just give out loads of information on how bad the world is, but to be aware of the history while trying to give solutions.

This is especially critical, as many scholars have noted the provision of information does not automatically lead to action and reflection (Blake, 1999; Shove, 2010), and education must reflect the need for critical thinking and action-oriented approaches. While the Secretary-General of the United Nations stated that, 'the capacity of teachers are key factors in empowering youth as a globally connected engine for change'(United Nations Secretary General, 2014), this often focuses on techno-centric and neoliberal responses (Cam, 2004). Ideas such as degrowth are rarely discussed (Cosme et al., 2017).

These discourses support the view of Sterling (2013) that education for sustainability in universities is pivotal, preparing future professionals with the tools and knowledge to drive change and instigate challenging debate, as embedded in SDG\#4.7. These responses suggest an appetite for a common sustainability narrative across Cardiff University, yet this is not evident in all Schools or disciplines.

\section{Researching and educating for sustainability}

The need for a dual approach when researching and educating for sustainability is wholly agreed upon (Sterling, 2013; Ralph and Stubbs, 2013), yet sustainability is not fully incorporated into the curriculum across all disciplines at Cardiff University. Cardiff University is divided into 24 Schools based on disciplinary alignment. 
Participant 1 outlined that environmental-related subjects (e.g. geography or environmental politics) are perhaps more likely to offer sustainability modules, while other disciplines tend to neglect sustainability. Some interviewees noted that it may be difficult to get people interested in sustainability if it seems to lack relevance to their studies. Often, university students receive little education about sustainability unless their subject specifically involves it (Martins et al., 2006), and even then, it can be optional. However, as noted by Participant 3 above, climate change affects all aspects of life (Madden, 2019) and thus has relevance to all disciplines.

Understanding the importance of environmental sustainability, some staff pushed for sustainability-based modules in their curricula where these were previously absent. Participant 4 commented that:

It met a lot of resistance in the School at first. Even people in the School didn't believe there was a market for it. However, the growing student numbers proves this to be wrong.

Given the recognition above that educating for sustainability is crucial, it is surprising that interviewees' responses failed to show evidence of this at Cardiff University. But, as mentioned, many universities have remained quite traditional in their methods, binding academic transitions to old mechanisms (Lozano et al., 2011), which inevitably delays the process of making sustainability an integral part of academia. Participant 3 acknowledged the challenges faced in getting sustainability incorporated into the curricula, and asserts that 'elective modules in a few departments is far from instilling a sustainability narrative across the university'. While it may be more challenging to educate students on sustainability in certain subjects, it is, nonetheless, necessary for a low-carbon transformation to occur. For instance, Participant 4 noted that:

The majority of people who come to the Business School are leaning towards commercial success in their lives. They are ambitious for material wealth; protecting the environment is far down their list of priorities.

Writing almost 15 years ago, Martins et al. (2006) recommended higher-education institutions transform their educational systems to encourage the implementation of new courses and/or subjects in this area. Hence, to educate all students in sustainability at Cardiff University, training for those whose subjects are not directly based on sustainability must be considered. This seems to miss an opportunity, however, as transitioning business practice is just as important as transformations in 
other areas - the concept of a Green Deal is finding traction (Knuth, 2018), and many businesses are established around the concept of green entrepreneurship (Gibbs and O’Neill, 2014). Embedding such thinking into the Business School curricula, for example, could thus go a long way in promoting sustainability and thinking about responses to climate change.

In terms of researching for sustainability, some participants felt that Cardiff University could be utilising their knowledge capabilities further to push the sustainability agenda. Participant 2 claims that research-led teaching is most effective in educating students, but vents frustration that researchers across Cardiff University do not work together with Schools coherently:

The Sustainable Places Research Institute doesn't give enough of a contribution; they should give their research to the lecturers in order to teach the students through research.

The above dialogues suggest a lack of cohesion across Cardiff University, missing an opportunity to exploit research expertise to provide students with contemporary sustainability knowledge. Given that Cardiff University already has experts in sustainability, this could be delivered at a relatively low cost, while simultaneously achieving SDG\#4 to provide quality education to all. Universities should prioritise research-led teaching across all departments, thus exposing students to contemporary sustainability research findings.

Linking to other prominent issues: the COVID-19 pandemic has rapidly changed existing practices in many ways, and in the higher-education context, this imposed a switch to online teaching (Bryson and Andres, 2020). Some argue that this gives a unique opportunity to improve student experience by introducing a bimodal approach, whereby the curation of learning experience is at the fore (Bryson and Andres, 2020). This, suggestively, highlights that rapid changes are possible, and that this transformation to education creates an opportunity to weave sustainability into the new learning approach, with potential to embed pro-environmental behaviour into students' minds.

Participant 12 asserts that in order to fully embed sustainability across Cardiff University there must be a 'complete shift in the way things are being done'. In order to determine whether a transformative shift is underway, the following section analyses how Cardiff University is implementing sustainable practice in its operations. 
Regarding the second research question, exploring how Cardiff University is integrating sustainability into its practical operations, I interviewed the estates-based staff responsible for managing Cardiff University's physical infrastructure. A narrative around campus sustainability has emerged internationally (Gormally et al., 2019: 124), suggesting that higher-education institutions are attempting to better their environmental performance.

'Green buildings' are recognised as essential in tackling climate change, given that buildings and construction account for some 45 per cent of total carbon emissions (Khan et al., 2019; O’Neill and Gibbs, 2018). In the higher-education context, Participant 13 outlines the issues of Cardiff University's campus, stating:

Not being a single-site university causes issues as people think of themselves as being in their own little silo - not thinking about the overall university agenda. Every site must be treated differently, because they are so different.

Operating over multiple sites can cause conflicting agendas, hindering the goal to embed a sustainability narrative across Cardiff University. This aligns with Adomßent et al.'s, (2019) observation that compartmentalisation of universities often makes it difficult for people to collaborate across departmental boundaries, constraining sustainability efforts to small islands of activity.

Cardiff University, like other older universities, has listed buildings, which, 'stops us from doing a lot of things that we would like to do'(Participant 13). Similarly, Participant 12 recognises the barriers caused by listed buildings, but proclaims: 'if we can't retrofit these buildings in terms of changing structure, we can definitely try to get our energy from better sources'. This corresponds to the university's ESAP (2018), which seeks to be carbon neutral for estates and campus facilities operations by 2023, ensuring renewable sources are adopted for all utilities. The adoption of renewable energy is especially critical to ensure SDG\#9 is met: upgrading infrastructure to use clean and environmentally sound technologies (United Nations, 2015).

Given that Cardiff University is not (yet) operating in the most sustainable way, participants were asked what they felt the barriers to acting sustainably were. Participant 8 claims that, in terms of estates: 
Cost has a major impact on whether we will or won't do something. We know what we could do, but simply do not have the money at the moment.

A rapid transition from fossil fuels to low-carbon technologies will cost up to 3 per cent of global GDP, meaning the necessary investments are yet to materialise (Webster, 2018). But many suggest that the costs of inaction (such as unmitigated climate change) are far greater than the initial investment (Stern, 2006), meaning environmental sustainability should be prioritised now. Despite upfront costs, campuses can potentially reap benefits through saving money on more sustainable practices while demonstrating new and clean technologies (Dahle, 2001), although such approaches clearly align with ecological modernisation (Young, 2015). Cardiff University state in their Carbon Management Plan 2014-2020(2013) that investing in energy-efficient technologies will ensure over $£ 1$ million financial savings on their gas and electricity bills in 2019/20. Yet there are doubts concerning whether energyefficiency improvements reduce overall resource use, with scholars proposing that such technological changes can produce a 'rebound effect' of increased overall energy consumption (Binswanger, 2001), ultimately resulting in higher energy consumption. While energy-efficient technology may cut costs, savings may be invested elsewhere (Chitnas et al., 2014). Therefore, technological improvements cannot be considered without associated social change.

Some participants asserted that, although cost is an issue, better decisions could be made to prioritise sustainability. Participant 3 noted:

Money is inevitably going to be the biggest issue, but people aren't looking at the long-term view. Today's money is restricted so we don't build the best building possible - we build something just so it's there. We are far too shortterm with things.

Taking this approach locks future generations into higher emissions and being reliant on fossil fuels as buildings built today will have lifetimes of 50 years or more (Dahmen et al., 2018). As Whitmarsh et al., (2011) have argued, individuals often do not feel climate change poses a personal, prominent threat; instead, they see the impacts as distant and thus fail to act accordingly. This reiterates the necessity of enhanced education on sustainability to induce effective policy change. Essentially, investing in long-term strategies may be a more practical solution for universities to create more sustainable environments. 
Reinvention: an International Journal of Undergraduate Research 14:1 (2021) Additionally, Participants 8 and 13 emphasised that Cardiff University is a researchintensive institution requiring a lot of equipment, which is not necessarily 'good' for the environment but is nevertheless seen as essential for research activities. The 20 research-intensive institutions that belong to the Russell Group collectively contribute to over half of the UK's university carbon emissions (Gormally et al., 2019). Being a Russell Group member, Cardiff University has departments whose research requires energy-consuming scientific equipment. Participant 13 noted:

I understand a lot of departments are doing research which requires a lot of power, but there are definitely questions surrounding whether they are looking at lower power options or not.

Participant 8 concurred:

Seeing as we are a research-intensive university, we should be investing in new environmentally friendly technologies.

These dialogues assert that Cardiff University could be seeking alternative technologies that will have less impact on the environment. Yet, often 'doing the science' overrules energy-related decisions (Gormally et al., 2019), suggesting that research excellence competes with sustainability in the higher-education context and potentially challenges the role of universities as leaders in this field.

Cardiff University has recently signalled the importance of sustainability through the appointment of a new Dean of Sustainability, designated as a: 'high profile champion for environmental sustainability' (Participant 3, 2019). Many interviewees emphasised the potential for this to ignite sustainability efforts, providing strategic direction for the environmental sustainability agenda at a senior level. As this is a new role, it is impossible to predict the exact outcome on sustainability trajectories. However, scholars assert that senior managerial support is crucial for long-term sustainability, yet organisations often fail to appoint a sustainability coordinator as they are perceived as a financial burden (Ávila et al., 2017; Wright and Nyberg, 2014). Thus, the appointment of a senior role for sustainability indicates Cardiff University's commitment to sustainability across the institution, striving towards long-term environmental sustainable development. Following the appointment of the new Dean of Sustainability, Cardiff University declared a climate emergency, proclaiming that, 'the climate crisis requires urgent response and, from now on, we intend to do things differently' (Cardiff University, 2019). This role has the potential to fix many 
Reinvention: an International Journal of Undergraduate Research 14:1 (2021)

aforementioned issues, giving hope for future sustainability at Cardiff University, but the proof of how differently things will be done remains to be seen.

\section{Conclusion}

This research adds to the growing body of literature on the organisational sustainability debate, accentuating the complexity involved in incorporating sustainability in the higher-education context. In line with the existing literature, this paper elaborates on department-wide awareness regarding the importance of prioritising sustainable trajectories. Higher-education institutions undeniably have a moral responsibility to act on the global environmental crisis (Humphreys, 2019), with many declaring a climate emergency in response. However, they are still grappling with how best to proceed, delaying the process of translating climate declarations into positive action. This research discovers that environmental sustainability efforts, so far, have been hindered by a lack of clarity across departmental boundaries - regarding both educational and operational procedures. Universities must be empowered to catalyse and implement new paradigms; adopting a collaborative approach to embed sustainable development across all elements (Chowdhury et al., 2019; Lozano et al., 2011).

Notwithstanding this, the COVID-19 pandemic has drastically changed the way universities operate. Such changes have generally had a positive environmental impact so far, yet long-lasting impacts remain undetermined. There are several key 'axes of uncertainty' about how the pandemic will unfold, but it has nevertheless forced universities to implement radical operational transformations (Majowicz, 2020). Robinson and Maitra (2020: 4) note that 'the post-COVID-19 world offers a rare opportunity to reform the education sector for generations to come. It would be imprudent to miss that opportunity'. With their extensive research and knowledge capabilities, higher-education institutions could impose progressive strategies towards fostering ecologically sound institutions, in terms of both practical operations and environmental literacy. Embedding sustainability into the minds of students may be a promising step towards a sustainable future.

The changing role of stakeholders in the environmental arena has meant involvement from all levels of governance is necessary to achieve a sustainable society (Berger, 2010). Thus, further research on the sustainability debate is essential to understand how organisations are implementing this. This paper corroborates the effect highereducation institutions can have in adhering to better sustainable practice, while 
Reinvention: an International Journal of Undergraduate Research 14:1 (2021) simultaneously preparing students to be future sustainable citizens. Future research could compare the performance to other higher-education institutions. A cohesive strategy towards environmental sustainability could be developed, bringing universities together to form an alliance that embeds a common sustainability narrative, such as having a collective sustainability protocol for the Russell Group universities. This research effectively allowed for rich examination into sustainability in one university, and can hopefully assist other higher-education institutions to improve their environmental practice.

\section{References}

Adomßent, M., A. Grahl and F. Spira. (2019), 'Putting sustainable campuses into force: Empowering students, staff and academics by the self-efficacy Green Office Model', International Journal of Sustainability in Higher Education, 20 (3), 470-81

Aldunce, P., J. Handmer, R. Beilin and M. Howden (2016), 'Is climate change framed as “business as usual” or as a challenging issue? The practitioners' dilemma', Environment and Planning C: Government and Policy, 34, 999-1019

Ávila, L., W. Filho, L. Brandli, C. Macgregor, P. Molthan-Hill, P. Özuyar and R. Moreira (2017), 'Barriers to innovation and sustainability at universities around the world', Journal of Cleaner Production, 164, 1268-78

Berger, G. (2010), 'Reflections on governance: Power relations and policy making in regional sustainable development', Journal of Environmental Policy \& Planning, 5 (3), 219-34

Bevir, M. (2008), Key Concepts in Governance, Thousand Oaks: Sage Publications

Biedenweg, K., M. Monroe and A. Oxarart (2013), 'The importance of teaching ethics of sustainability', International Journal of Sustainability in Higher Education, 14 (1), 6-14

Binswanger, M. (2001), 'Technological progress and sustainable development: what about the rebound effect?', Ecological Economics, 36, 119-32

Blake, J. (1999), ‘Overcoming the "value-action gap” in environmental policy: Tensions between national policy and local experience', Local Environment, 4 (3), $257-78$ 
Braun, V. and V. Clarke (2013), Successful Qualitative Research: A Practical Guide for Beginners, Thousand Oaks: Sage Publications

Bryson, J. R. and L. Andres (2020), 'Covid-19 and rapid adoption and improvisation of online teaching: Curating resources for extensive versus intensive online learning experiences', Journal of Geography in Higher Education, 44 (4), 608-23

Cam, C. N. (2004), 'A conceptual framework for sociotechno-centric approach to sustainable development', International Journal of Technology Management \& Sustainable Development, 3 (1), 59-66

Cardiff University (2013), ‘Cardiff University Carbon Management Plan', available at: https://www.cardiff.ac.uk/_data/assets/pdf_file/0013/203134/CarbonManagement-Plan.pdf, accessed 10 June 2019

Cardiff University (2018), ‘Environmental Sustainability Action Plan', available at: https://www.cardiff.ac.uk/_data/assets/pdf_file/0009/1272951/Environmentalsustainability-enabling-strategy-action-plan-2018_2.pdf, accessed 10 June 2019

Cardiff University (2018), ‘Environmental Sustainability Enabling Strategy’, available at: https://www.cardiff.ac.uk/_data/assets/pdf_file/0006/1197555/SustainableStrat. pdf, accessed 10 June 2019

Cardiff University (2019), 'Cardiff University declares climate emergency’, available at: https://www.cardiff.ac.uk/news/view/1730638-cardiff-university-declares-climateemergency, accessed 02 December 2019

Castree, N., A. Rogers and R. Kitchin (2013), A Dictionary of Human Geography, Oxford: Oxford University Press

Chitnas, M., S. Sorrell, A. Druckman, S. K. Firth and T. Jackson (2014), 'Who rebounds most? Estimating direct and indirect rebound effects for different UK socioeconomic groups', Ecological Economics, 16, 12-32

Chowdhury, R., E. Munroe and A. Bremond (2019), 'Editorial overview: Seeking solutions to land challenges of the Anthropocene: A land systems science perspective', Current Opinion in Environmental Sustainability, 38, A1-A5

Clarke, A. and R. Kouri (2009), 'Choosing an appropriate university or college environmental management system', Journal of Cleaner Production, 17 (11), 971984 
Conca, K., T. Princen and M. F. Maniates (2001), 'Confronting consumption', Global Environmental Politics, 1 (3), 1-9

Cosme, I., R. Santos and D. W. O'Neill (2017), 'Assessing the degrowth discourse: A review and analysis of academic degrowth policy proposals', Journal of Cleaner Production, 149, 321-34

Creighton, J. L. (1999), 'Public participation in federal agencies' decision making in the 1990s', National Civic Review, 88 (3), 249-58

Cresswell, J. W. and P. Clark (2011), Designing and Conducting Mixed Method Research, Thousand Oaks: Sage Publications

Crutzen, P. J. (2006), 'The "Anthropocene”', in Ehlers, E. and K. Thomas (ed.), Earth System Science in the Anthropocene, Berlin: Heidelberg, pp. 13-18

Dahle, M. (2001), 'Overcoming barriers to campus greening: A survey among higher educational institutions in London, UK', International Journal of Sustainability in Higher Education, 2 (2), 139-60

Dahmen, J., J. Von Bergmann and M. Das. (2018), 'Teardown index: Impact of property values on carbon dioxide emissions of single family housing in Vancouver', Energy and Buildings, 170, 95-106

Drever, E. (1995), Using Semi-Structured Interviews in Small-Scale Research. A Teacher's Guide, Edinburgh: Scottish Council for Research in Education

Elliot, M., I. Fairweather, W. Olsen and M. Pampaka (2016), A Dictionary of Social Research Methods, Oxford: Oxford University Press

Elo, S. and H. Kyngäs (2008), 'The qualitative content analysis process', Journal of advanced nursing, 62 (1), 107-15

Evans, B. and K. Theobald (2003), 'Local Agenda 21 and the shift to "soft governance"' in Buckingham, S. and K. Theobald (eds.), Local Environmental Sustainability, Burlington: Elsevier Science, pp. 74-92

Evans, J., R. Jones, A. Karvonen, L. Millard and J. Wendler (2015), 'Living labs and coproduction: University campuses as platforms for sustainability science', Current Opinion in Environmental Sustainability, 16, 1-6 
Gerring, J. (2006), Case study research: Principles and practices, Cambridge University Press

Gibbs, D. and K., O’Neill (2014), ‘Rethinking sociotechnical transitions and green entrepreneurship: The potential for transformative change in the green building sector', Environment and Planning A., 46, 1088-107

Gills, B., J. Morgan (2020), 'Global Climate Emergency: after COP23, climate science, urgency, and the threat to humanity', Globalizations, 17 (6), 885-902

Gormally, A., K. O’Neill, M. Hazas, O. Bates and A. Friday (2019), “'Doing good science": The impact of invisible energy policies on energy demand in higher education', Energy Research and Social Science, 52, 123-31

Hamilton, C. (2016), 'The Anthropocene as rupture', Anthropocene Review, 3 (2), 93106

Hoover, E. and M. Harder (2015), 'What lies beneath the surface? The hidden complexities of organisational change for sustainability in higher education', Journal of Cleaner Production, 106, 175-88

Humphreys, D. (2019), 'Pedagogies of change: Rethinking the role of the university during the climate emergency', The International Journal of Environmental, Cultural, Economic, and Social Sustainability: Annual Review, 15 (1), 53-70.

Huxley, R., A. Owen and P. Chatterton (2019), 'The role of regime-level processes in closing the gap between sustainable city visions and action', Environmental Innovation and Societal Transitions, 33, 115-26

Jamshed, S. (2014), 'Qualitative research method - interviewing and observation', Journal of Basic and Clinical Pharmacy, 5 (4), 87-88

Khan, J. S., R. Zakaria, S. M. Shamsudin, N. I. A. Abidin, S. R. Sahamir, D. N. Abbas and E. Aminudin (2019), 'Evolution to emergence of green buildings: A review', Administrative Sciences, 9 (1), 1-20

Knuth, S. (2018), “"Breakthroughs” for a green economy? Financialization and clean energy transition', Energy Research \& Social Science, 41, 220-29

Kopnina, H. (2012), 'Education for sustainable development (ESD): The turn away from 'environment' in environmental education?', Environment Education Research, 18 
Kopnina, H. (2016), 'The victims of unsustainability: A challenge to Sustainable Development Goals', International Journal of Sustainable Development \& World Ecology, 23 (2), 113-21

Lozano, R., R. Lukman, F. Lozano, D. Huisingh and W. Lambrechts (2011),

'Declarations for sustainability in higher education: Becoming better leaders, through addressing the university system', Journal of Cleaner Production, 48, 1019

Madden, D. (2019), 'Editorial: City of emergency’, City, 23 (3), 281-84

Majowicz, S. E. (2020), 'What might the future bring? COVID-19 planning considerations for faculty and universities', Epidemiology and Infection, 148, 1-5

Martins, A., T. Mata and C. Costa (2006), 'Education for sustainability: Challenges and trends', Clean Technologies and Environmental Policy, 8 (1), 31-37

Masson-Delmotte, V., P. Zhai, H. O. Pörtner, D. Roberts, J. Skea, P.R. Shukla, A. Pirani, W. Moufouma-Okia, C. Péan, R. Pidcock, S. Connors, J.B. Matthews, Y. Chen, X. Zhou, M.I. Gomis, E. Lonnov, T. Maycock, M. Tignor, T. Waterfield. (2018), Global Warming of $1.5^{\circ} \mathrm{C}$. An IPCC Special Report on the impacts of global warming of $1.5^{\circ} \mathrm{C}$ above pre-industrial levels and related global greenhouse gas emission pathways, in the context of strengthening the global response to the threat of climate change, sustainable development, and efforts to eradicate poverty', available at https://report.ipcc.ch/sr15/pdf/sr15_spm_final.pdf, accessed 12 September 2019

McCullough, B., M. Pfahl and S. Nguyen (2016), 'The green waves of environmental sustainability in sport', Sport in Society, 19 (7), 1040-65

Mol, A. P. J. and G. Spaargaren (2000), 'Ecological modernisation theory in debate: A review’, Environmental Politics, 9 (1), 17-49

Moore, J. (2005), 'Barriers and pathways to creating sustainability education programs: Policy, rhetoric and reality', Environmental Educational Research, 11 (5), 537-55

O’Neill, D. W., A. L. Fanning, W. F. Lamb and J. K. Steinberger (2018), 'A good life for all within planetary boundaries', Nature Sustainability, 1 (2), 88-95 
Reinvention: an International Journal of Undergraduate Research 14:1 (2021)

O’Neill, K. and D. Gibbs (2018), 'Green building and sustainability: Diffusing green

building approaches in the UK and Germany', in Brinkmann, R. and S. Garren (ed.),

'The Palgrave Handbook Of Sustainability: Case Studies And Practical Solutions',

London: Palgrave, pp. 547-65

Palinkas, L., S. Horwitz, C. Green, J. Wisdom, N. Duan and K. Hoagwood (2015),

'Purposive sampling for qualitative data collection and analysis in mixed method implementation research', Administration and Policy in Mental Health, 42 (5), 53344

Pesqueux, Y. (2009), 'Sustainable development: A vague and ambiguous theory', Society and Business Review, 4 (3), 231-45

Pierantoni, I. (2004), 'A few remarks on methodological aspects related to sustainable development', in Organisation for Economic Co-operation and Development (ed.), Measuring Sustainable Development, Paris: OECD Publishing, pp. 63-89

Piza, V., J. Aparicio, C. Rodríguez, R. Marín, J. Beltrán and R. Bedolla (2018), 'Sustainability in higher education: A didactic strategy for environmental mainstreaming', Sustainability, 10 (12), 1-12

Ragazzi, M. and F. Ghidini (2017), 'Environmental sustainability of universities: Critical analysis of a green ranking', Energy Procedia, 119, 111-20

Ralph, M. and W. Stubbs (2013), 'Integrating environmental sustainability into universities', Springer, 67 (71), 71-90

Ramos, T., S. Caeiro, B. Hoof, R. Lozano, D. Huisingh, and K. Ceulemans (2015), 'Experiences from the implementation of sustainable development in higher education institutions: Environmental Management for Sustainable Universities', Journal of Cleaner Production, 106, 3-10

Robinson, J. and S. Maitra (2020), 'Higher education after COVID-19 - Policy brief', SSRN Electronic Journal, Available at:

https://www.researchgate.net/deref/http\%3A\%2F\%2Fdx.doi.org\%2F10.2139\%2Fssr n.3604670, accessed 27 April 2021

Sachs, J. (2015a), 'Achieving the Sustainable Development Goals', Journal of International Business Ethics, 8 (2), 53-62 
Sachs, J. (2015b), The Age of Sustainable Development, Columbia: Columbia University Press

Shove, E. (2010), 'Beyond the ABC: Climate change policy and theories of social change', Environment and Planning A, 42 (6), 1273-85

Sikdar, S. (2012), 'Measuring sustainability', Clean Technologies and Environmental Policy: Berlin, 14 (2), 153-54

Silverman, D. (2001), Interpreting Qualitative Data: Methods for Analysing Talk, Text and Interaction, London: Sage Publications

Soini, K., A. Jurgilevich, J. Pietikäinen and K. Korhonen-Kurki (2018), 'Universities responding to the call for sustainability: A typology of sustainability centres', Journal of Cleaner Production, 170, 1423-32

Sterling, S. (2013), 'The sustainable university: Challenges and response'. In: Sterling, S., L. Maxey., H. Luna (eds.), The Sustainable University: Progress and Prospects, Abingdon: Routledge, pp. 17-50

Stern, N. H. (2006), The Economics of Climate Change: The Stern Review, Cambridge: Cambridge University Press

Stough, T., K. Ceulemans, W. Lambrechts and V. Cappuyns (2016), 'Assessing sustainability in higher education curricula: A critical reflection on validity issues', Journal of Cleaner Production, 172, 4456-66

Taylor, S., R. Bogdan and M. DeVault (2015), Introduction to Qualitative Research Methods: A Guidebook and Resource, John Wiley and Sons

United Nations (2015), Sustainable Development Goals, available at: https://sustainabledevelopment.un.org/?menu=1300 accessed 28 September 2019

United Nations Secretary General (UNSG), (2014), 'The road to dignity by 2030: Ending poverty, transforming all lives and protecting the planet', Synthesis Report of the Secretary-General on the Post-2015 Sustainable Development Agenda, New York: United Nations

United Nations World Commission on Environment and Development (UNWCED), (1987), 'Our common future', in Brundtland, G. H. (ed), Report of the World 
Commission on Environment and Development, Brundtland, Oxford: Oxford University Press

University Leaders for a Sustainable Future (ULSF), (1990), The Talloires Declaration, Washington: ULSF

Vogt, W. P. (1999), Dictionary of Statistics and Methodology: A Nontechnical Guide for the Social Sciences, London: Sage Publications

Wals, A. E. (2014), 'Sustainability in higher education in the context of the UN DESD: A review of learning and institutionalization processes', Journal of Cleaner Production, 62, 8-15

Wang, Y., H. Shi, M. Sun, D. Huisingh, L. Hansson and R. Wang (2013), 'Moving towards an ecologically sound society? Starting from green universities and environmental higher education', Journal of Cleaner Production, 61, 1-5

Webster, A. (2018), 'A global consumer-led strategy to tackle climate change', Physics and Society, 1

Wellbeing of Future Generations (Wales), Act 2015, (2015), available at:

https://www.futuregenerations.wales/about-us/future-generations-act/ accessed 30 June 2019

Welsh Assembly Government, (2016), 'Legislation for sustainable development to secure the long term well-being of Wales', available at:

https://gov.wales/sites/default/files/publications/2019-05/sustainabledevelopment-legislation.pdf, accessed 30 June 2019

Welsh Assembly Government, (2019), 'Wales and the Sustainable Development Goals Supplementary Report to the UK Voluntary National Review 2019', available at: https://futuregenerations.wales/wp-content/uploads/2019/07/Wales-_-SDGs-_VNR- -Supplementary-Report-for-Wales- -Version-10.1-Final-w-cover-ENG.pdf, accessed 30 June 2019

Whitmarsh, L., G., Seyfang and S. O’Neill (2011), 'Public engagement with carbon and climate change: To what extent is the public “carbon capable”?', Global Environmental Change, 21, 56-65

Wright, C. and D. Nyberg (2014), 'Creative self-destruction: Corporate responses to climate change as political myths’ Environmental Politics, 23 (2), 205-23 
Young, S. (2015), The Emergence of Ecological Modernisation: Integrating the

Environment and the Economy? London: Routledge

\section{Appendix}

Appendix 1: Semi-structured interview guide 1 (estates-based participants)

1. What is your role at Cardiff University?

2. How long have you been at Cardiff University?

3. What interests you in the field of sustainability?

4. Why is acting sustainably important?

5. What factors are influencing sustainable practice?

6. Can you give examples of how your department/school are working towards better sustainable practice?

7. Do you consider your department/school to be sustainable?

8. Are there any barriers that stop you from acting sustainably?

9. Are you aware of the university's sustainability strategy? If so, how are you supporting it?

10. Do you have any future plans regarding sustainable practice?

11. Are there any institutional changes that would make a difference but are yet to be implemented?

12. Could changes in national policy have an impact on the way in which Cardiff University tackle sustainability?

13. Is there anything you would like to add or any questions you were expecting that I haven't asked?

Appendix 2: Semi-structured interview guide 2 (research- and education-based participants)

1. What is your role at Cardiff University?

2. How long have you been at Cardiff University?

3. What interests you in the field of sustainability?

4. What does your main research entail?

5. What are the key themes that you research and/or teach?

6. What do you think the importance of researching and educating people about sustainability is? 
7. Why do you think people are interested in researching and studying sustainability?

8. Why do you think people aren't interested in researching and studying sustainability?

9. What do you think the barriers for getting people interested in the topic of sustainability are?

10. Given that environmental degradation is more of a concern to many in recent times, are you seeing an increase in the number of people interested in this topic?

11. Do you have any future plans regarding sustainability in your teaching and/or research?

12. Are there any barriers to your research?

13. Is there anything that you'd like to add or any questions you were expecting that I haven't asked?

To cite this paper please use the following details: Sinden, C.K. (2021), 'Incorporating Sustainability into the Academic Institution', Reinvention: an International Journal of Undergraduate Research, Volume 14, Issue 1, https://reinventionjournal.org/article/view/722. Date accessed [insert date]. If you cite this article or use it in any teaching or other related activities please let us know by emailing us at Reinventionjournal@warwick.ac.uk. 